\title{
TAKAKURA TRAINING FOR COMMUNITY EMPOWERING IN MANAGING DOMESTIC WASTE AT KAMPUNG TENGAH, KRAMAT JATI, JAKARTA TIMUR
}

\author{
Ira Mulyawati, Ninin Gusdini, Laila Febrina \\ Universitas Sahid, Indonesia \\ iramulyawati@gmail.com
}

\begin{abstract}
One of the bigest problems cities in Indonesia such as Jakarta is still cannot be solve properly the problem of urban waste. The amount of municipal solid waste of DKI Jakarta based on data from the Ministry of Environment and Forestry in the 2017-2018 period is 6234.44 tons / day with 1.85 tons / day sourced from the city of East Jakarta. East Jakarta with its main market namely Kramat Jati market has a fairly complicated municipal waste problem, this has an impact on the amount of waste around the wholesale market, one of which is the village of Kampung Tengah. Kampung Tengah has a quite serious waste problem because the waste is not only produced from household waste, but from onion peeler craftsmen who later the onions are sold to the Kramat Jati market. To overcome these problems, one of the solution is by empowering the community in managing household waste. Therefor, Kampung Tengah communities are given knowledge about waste management through training. The training conducted is about how to use methods that are easy to apply and effective in reducing the amount of waste generation, namely the Takakura method. Participants given the training were focused on RW.10 with 25 participants. The result of the training is that the community has been able to apply the Takakura method to make compost from household waste.
\end{abstract}

Keywords : Compost, Waste, Takakura, Urban, Kampung Tengah

\section{INTRODUCTION}

At present almost all major cities in Indonesia and even in the world face problems related to waste management. Waste becomes a big problem, especially in Indonesia, because it's included in the top 10 countries with the largest population in the world. The high number of population causes the amount of waste generation in Indonesia is quite high. In addition, the waste management system in Indonesia, which in general still applies a waste collection system where the waste management is only concentrated in landfills (TPA), this causes waste not be treated properly.

The amount of municipal solid waste of DKI Jakarta based on data from the Ministry of Environment and Forestry in the 2017-2018 period is 6234.44 tons/day with 1.85 tons/day sourced from the city of East Jakarta. The amount of solid waste generation from the city of East Jakarta is because East Jakarta has a Kramat Jati main market. Activities in the Kramat Jati Main Market have an impact on the increasing amount of waste generated in the area around the market, one of which is Kelurahan Kampung Tengah.

This village has a quite serious problem because of the high amount of waste generation. This is caused by the high number of residents in the village of the middle village BPS data 2016 shows that in 2015 the village of Central Kampung has a population of around 49,917 people. In addition, the presence of onion peeler craftsmen in the village causes higher waste generation. The craftsman then sells peeled onions to the Kramat Jati main market.

The Waste problem is the responsibility of all parties including the community. Strengthening knowledge about waste management must continue to be promoted to the community so that the community can play an active role in unraveling the waste problem. Kelurahan Kampung Tengah itself already has independent waste management by making compost from household waste, but this is still centralized in RW. The only person who has been mobilized is Mr. Ramin Saaman, where there is only one processing plant with a building area of around $12 \mathrm{~m}^{2}$ so that the reduction in the amount of waste generated in the village of Central Kampung is still not significant

For this reason, it is necessary to strengthen knowledge and increase motivation so the people want to process their waste starting from their homes, one of which is by organizing waste management training. Training on waste management to the community must be easily understood and applied, one of the methods in processing household waste that is simple and easy is to use the Takakura method. 


\section{METHODS}

The method used in this training is the provision of modules, tools, and materials. Modules that contain procedures for waste management using the Takakura method are explained first to the community and then given to each participant. Tools and materials such as takakura baskets, rice husks, knives, cardboard as a cover for takakura baskets, shovels and compost as a starter was given to each RT representative to then do a compost simulation using the garbage that participants had brought from their homes.

\section{RESULTS AND DISCUSSION}

\section{Results}

The village of Kampung Tengah already has household waste processing into compost located at RT.06 RW. 10 with the driving force is Mr. Ramin Saaman. However, waste management has not had a significant impact on reducing waste in the village of Kampung Tengah. In addition, the lack of participation of the middle village community to process their household waste makes the problem of garbage in the village of Kampung Tengah not yet handled properly. For this reason, the purpose of this training is to provide knowledge to the community so that they can process their household waste and increase the community's role in dealing with environmental waste issues, especially in RW.10, Kampung Tengah Village so that the environment becomes clean, healthy and free of rubbish.

In this training, the guest speaker was Laila Febrina S.T., M.T. The daily activities of Ibu Laila are as a lecturer majoring in Environmental Engineering, Faculty of Engineering, Sahid University, Jakarta.

Processing of household organic waste such as rice, vegetables, and other organic waste into compost using the Takakura method was initiated by Japanese researcher Koji Takakura and was first implemented in Surabaya in 2004. The advantage of this method is that it does not cause odor, does not take up much time in processing. and the results can be directly utilized besides the most important for the treatment of urban waste is this method does not require a large area and capacity in accordance with the volume of organic waste that is disposed of daily by households. Materials and tools needed to implement this method can be seen in table 1.1

Table 1. Takakura method materials and tools

Materials and tools

\begin{tabular}{llll}
\hline - & Organic Trash: don't add meat, \\
fish, bones & $\bullet$ & Used cardboard \\
- & Compost & $\bullet$ & Hollow basket and lid \\
- Shovel / Stirrer & & \\
- Knife / Machete & \\
- Two pieces of Husk Pillows & \\
\hline
\end{tabular}

The arrangement of the takakura basket, you can see in Picture 1 below.

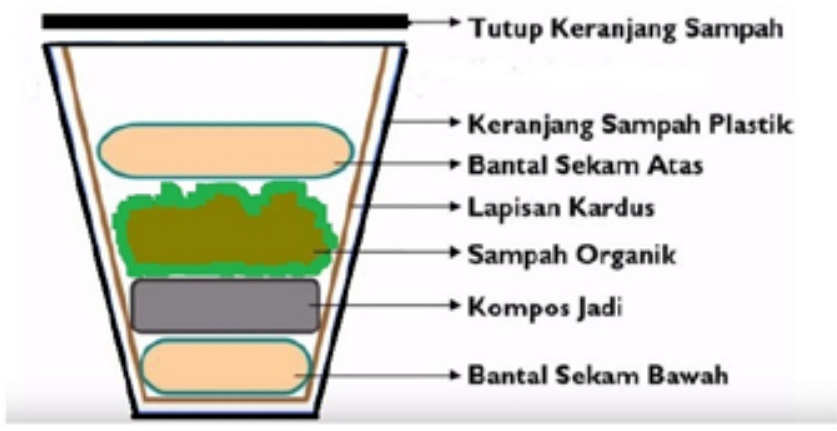

Picture 1. Takakura method basket arrangement 
The work steps for making fertilizer using the Takakura method can be seen more clearly in Picture 2 below.

There are several activities carried out in this training, the first is the stage of providing education and practice carried out on Thursday 1 November 2018 and the second is the evaluation phase. The first stage begins with the distribution of the Takakura method work step module followed by an explanation from the resource person Picture 2, then the practice of making compost by the participants is guided by the resource person Picture 3. Baskets that have been filled with organic waste fertilizer are carried by representatives of each RT to then be stored in a shady place and has good air circulation so that the waste can be a good compost fertilizer. The second stage is the evaluation phase, the activity carried out is an interview with some participants who took part in the training to find out the benefits they felt after attending the training, the next evaluation activity was carried out on November 15, 2018. This activity saw the results of compost made by the participants whether the garbage has become mature compost and can be used by the community

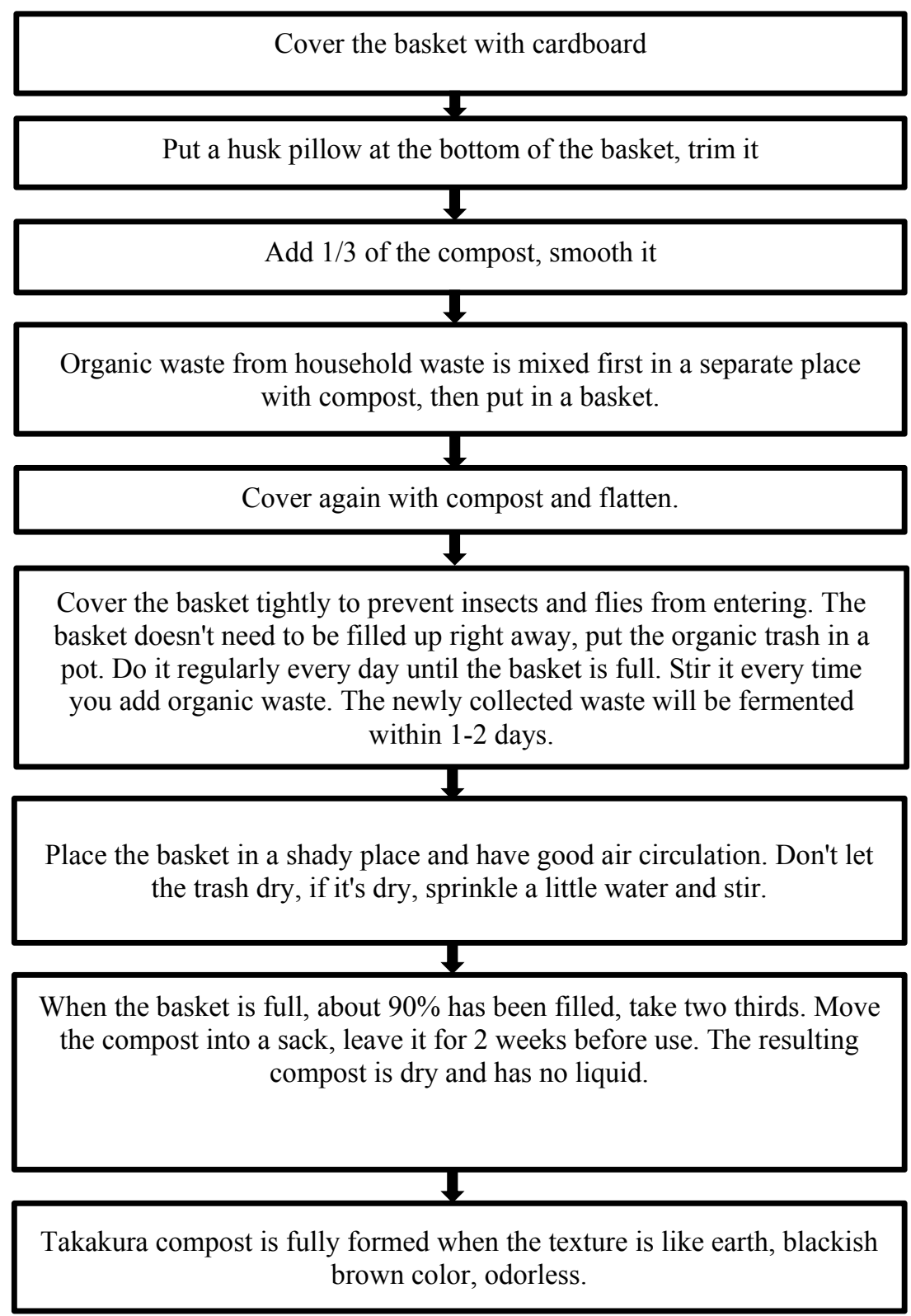

Picture 2. Takura method work steps 


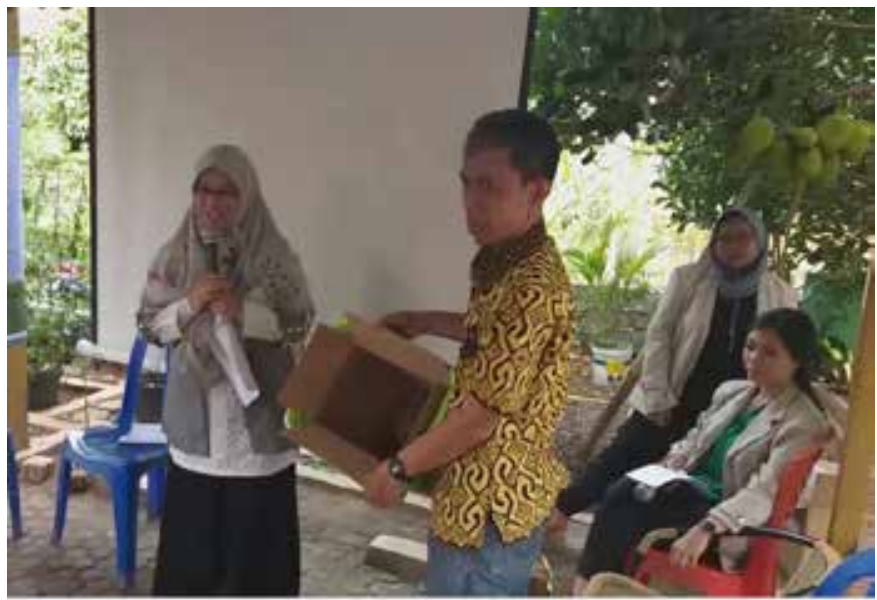

Picture 3. Explanation of the takakura method by the speaker

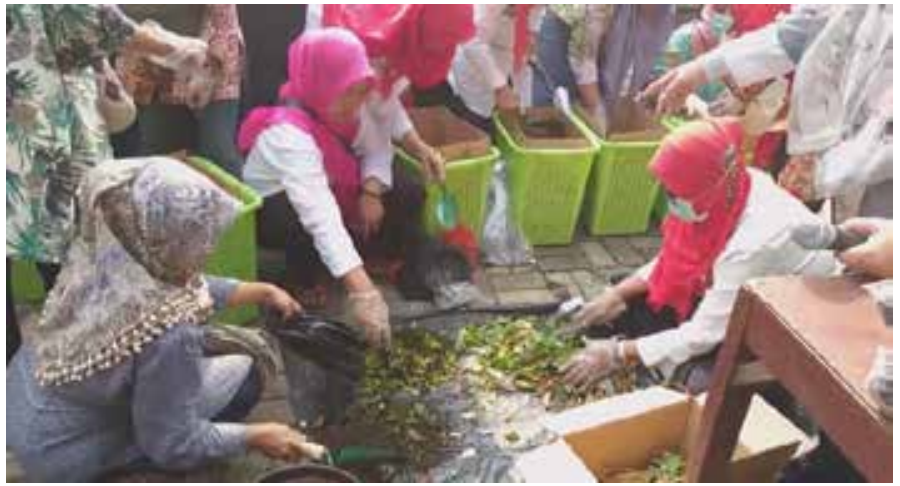

Picture 4. The practice of composting by the participants

The results of this training can be seen at the evaluation stage, where the interview stage conducted interviews with several participants who took part in the training to find out the benefits they felt Picture 4 . The result is that they have gained new knowledge on waste management that is easily implemented at the household scale thereby increasing their interest in being able to process their household organic waste. Besides that, from the results of the review two weeks after the community participated in the training, it was found that in all takakura baskets that were given household organic waste into compost Picture 5.

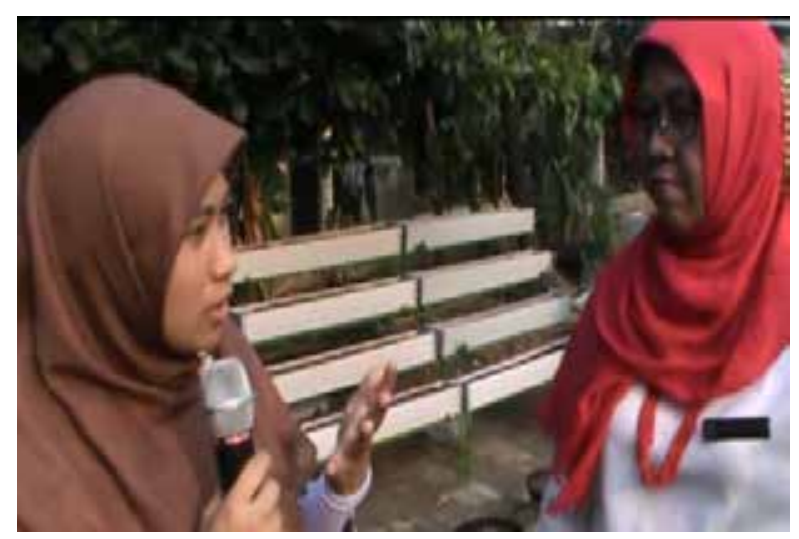

Picture 5. Interview with participants about the benefits of the training 


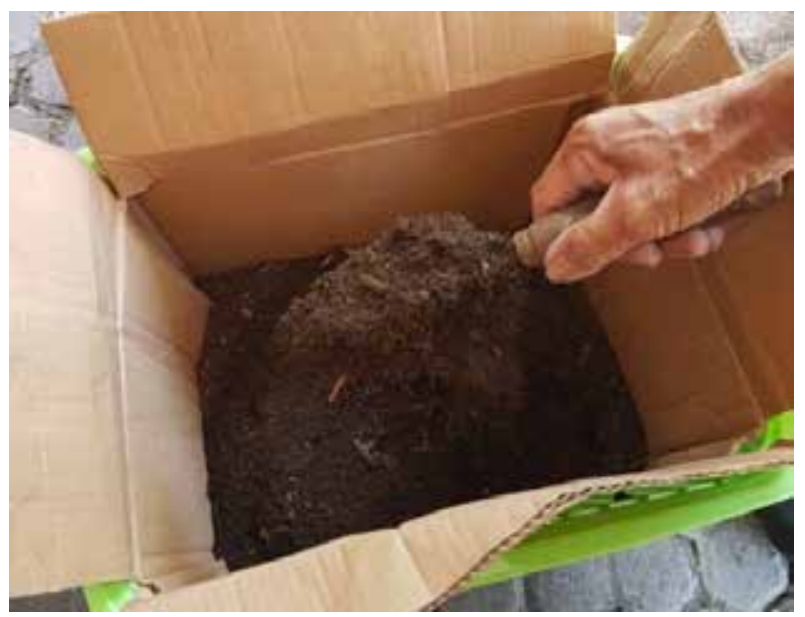

Picture 6. Takakura method compost fertilizers that have been rip

\section{Discussion}

In the results section, it has been mentioned that the village of Kampung Tengah already has its waste management but is still focused on one person as the mobilizer, Mr. Ramin Saaman, but has not had a significant impact on reducing waste generation. In addition, the lack of knowledge and motivation of the community to manage the organic waste of their households has caused the problem of garbage in the village of Kampung Tengah has not been handled properly.

The results of the training show the increasing interest of the community in managing their household organic waste, the community has also been able to apply the Takakura method to process household organic waste into compost.However, compost processing using the Takakura method is still centralized in each RT within the scope of the RW.10 area of Kampung Tengah and has not spread to all RWs in the Kampung Tengah Village, East Jakarta.

\section{CONCLUSION}

The conclusions that can be drawn from this training activity are:

1. This training has increased the interest and knowledge of the community to process their household organic waste using the Takakura method.

2. The community is more concerned about the surrounding environment and tries to keep their environment clean and free from the garbage.

3. The community realizes that waste which is considered worthless and is seen as an enemy of the community becomes a valuable and usable item.

\section{ACKNOWLEDGEMENT}

This research was funded by the Ministry of the Higher Education, Research and Technology of the Republic of Indonesia, through PPTTG program 2018 (Contract Number 197/SP2H/PPM/2018).

\section{REFERENCES}

Badan Penelitian dan Pengembangan Pertanian. (2013). Petunjuk Pelaksanaan Pengembangan Model Kawasan Rumah Pangan Lestari dan Sinergi Program TA 2013.

Badan Penelitian dan Pengembangan Pertanian, Kementerian Pertanian and Badan Pusat Statistik (BPS). (2016). Statistik Daerah Kramat Jati 2016. [internet]. [diunduh 2018 Oktober 12] Tersedia pada : http://www.jaktimkota.bps.go.id

Wahyono, S, Sahwan F.L and Suryanto. F. (2016). Kupas Tuntas dari A-Z Komposting Sampah Kota Skala Kawasan. BPPT PRESS; Jakarta

Japan International Cooperation Agency (JICA). (2016). Takakura Composting Method. JICA's World; Japan Epstein, E. (1997). The Science of Composting. Technomic Publishing Company, Inc,, US 